\title{
A novel mesoderm inducer, Madr2, functions in the activin signal transduction pathway
}

\author{
Julie C. Baker and Richard M. Harland ${ }^{1}$ \\ Department of Molecular and Cell Biology, University of California, Berkeley, California 94720 USA
}

\begin{abstract}
A functional assay to clone mouse mesoderm inducers has identified the mouse gene Mad related 2 (Madr2). Madr2 induces dorsal mesoderm from Xenopus ectoderm and can mimic the organizer in recruiting neighboring cells into a second axis. By analyzing the expression of a lacZ/Madr2 fusion protein, we find Madr 2 confined to the nucleus in the deep, anterior cells of the second axis, whereas in epidermal and more posterior cells the protein is cytoplasmically localized. This context-dependent nuclear localization suggests that in certain regions of the embryo, Madr2 responds to a localized signal and amplifies this signal to form the second axis. Furthermore, although Madr2 remains unlocalized in ectodermal explants, addition of activin enhances the concentration of Madr2 in the nucleus. Significantly, a functional lacZ fusion to a carboxy-terminal portion of Madr 2 is nuclear localized even in the absence of activin. This indicates that Madr 2 contains a domain that can activate downstream components and a repressive domain that anchors the protein in the cytoplasm. Nuclear localization of Madr 2 in response to activin, and the activin-like phenotypes induced by overexpression of Madr2, indicate that Madr2 is a signal transduction component that mediates the activity of activin.
\end{abstract}

[Key Words: Madr2; activin; mesoderm; nuclear localization]

Received May 10, 1996; revised version accepted June 25, 1996.

The crucial first step in patterning of the vertebrate embryo is the induction of mesoderm. In Xenopus, disruption of peptide growth factor signaling leads to loss of the mesoderm, supporting the idea that cell-cell communication, or induction, is responsible for mesoderm formation (Amaya et al. 1991; Hemmati-Brivanlou and Melton 1992). Several members of the transforming growth factor $\beta$ (TGF $\beta$ ) and fibroblast growth factor (FGF) families have been shown to have mesoderm-inducing activity (Kessler and Melton 1994; Slack 1994). However, to date, mutations in specific FGFs or activins have not implicated any of these molecules in mesoderm induction in the mouse (Deng et al. 1994; Vassalli et al. 1994; Yamaguchi et al. 1994; Feldman et al. 1995). One interpretation of these experiments is that additional activities are required in the mouse for mesoderm formation.

The formation of mesoderm in the mouse is mechanistically different from that in amphibians. In the cupshaped epiblast of the mouse embryo, mesoderm formation initiates in a population of ingressing cells adjacent to the embryonic/extraembryonic junction. This population forms the primitive streak, which initiates at one point on the rim of epiblast. Cells intercalate between the ectoderm and primitive endoderm of the streak, emerging as mesoderm (Hogan et al. 1994). In the mouse, the origin of mesoderm-inducing signals is unknown.

${ }^{1}$ Corresponding author.
These signals could emanate from the embryonic endoderm, the embryonic ectoderm, or even the extraembryonic ectoderm. Identifying molecules important in mammalian mesoderm formation has been difficult in part because of the small size and inaccessibility of the mouse embryo. However, analysis of naturally occurring or induced genetic mutations has been successful in identifying genes essential to mesoderm formation, such as nodal and brachyury. Embryos lacking nodal contain little or no mesoderm and fail to form and maintain the primitive streak (Conlon et al. 1991, 1994; Zhou et al. 1993). Brachyury mutant embryos do not generate enough mesoderm and have severe defects in the development of the notochord (Herrmann et al. 1990). Even though these approaches have yielded important molecules, the effort involved in generating mutations and subsequently isolating the molecules responsible for the defects is extensive.

To identify mouse genes involved in mesoderm formation, we have used a functional screen for mammalian molecules capable of inducing mesoderm in Xenopus ectodermal explants. Precedent for such a screen comes from observations that mammalian proteins can act on Xenopus tissues, even when the mammalian sequence has diverged considerably from the nearest Xenopus homolog (e.g., nodal and the Xenopus nodal-related genes; Jones et al. 1995). In some cases, a mouse gene is more potent than the frog homolog, perhaps because regulatory mechanisms that suppress activity of the protein in 
normal development are not conserved (Rupp et al. 1994).

Here we report the identification of a mouse transcript, Madr2, which causes mesoderm to form in Xenopus animal caps. Madr2 is similar to the Drosophila gene, mothers against dpp (Mad) (Sekelsky et al. 1995) as well as the human tumor suppressor gene DPC4 (Hahn et al. 1996). The sequence is very similar to Xmad2, which was recently isolated by sequence similarity to Drosophila Mad (Graff et al. 1996). We address the mode of action of Madr2 using animal cap and whole embryo assays. The clone isolated in the screen is a partial cDNA and encodes a truncated protein. This truncation functions similarly to the full length transcript, which was subsequently isolated. Using $l a c Z$ fusion proteins we show that nuclear localization of Madr2 can be induced by activin. In addition, the truncated form of Madr2, is localized exclusively in the nucleus with or without activin treatment. This suggests that the Mad proteins contain a domain that is sufficient to activate downstream components, and a regulatory domain, which anchors the protein in the cytoplasm.

\section{Results}

\section{Expression cloning of Madr2}

We have developed a screen for mouse molecules which can change the fate of Xenopus ectoderm to mesoderm. As a source for potential inducers, we made a cDNA library from mouse embryonic stem (ES) cells which had begun to differentiate into mesoderm. When cultured in the presence of leukemia inhibitory factor (LIF), ES cells can be introduced into mouse embryos and can contribute to all three germ layers (Beddington and Robertson 1989). However, in the absence of LIF, these cells can be cultured in vitro to differentiate into mesodermal derivatives (Robertson 1987). During differentiation, ES cells turn on genes such as nodal and brachyury (Johansson and Wiles 1995), suggesting that they may also turn on other genes in the normal mesoderm induction pathway. Poly $(A)^{+}$RNA was isolated from CCE ES cells after being grown without LIF for $24 \mathrm{hr}$ and a plasmid cDNA library constructed from this material.

The library of cDNAs was divided into 97 pools of 1000 clones each; these were used to synthesize capped mRNA that was injected into one-cell Xenopus embryos. At the blastula stage $(8-9)$, the ectoderm (animal cap) was explanted and grown in culture until gastrula stage (10.5). To examine whether the animal cap has become mesoderm in response to the injected RNA, the aged caps were analyzed for the expression of the mesodermal marker, Xbra (Fig. 2A, below). If the injected pool of synthetic RNAs contains a message which can instruct the ectoderm to become mesoderm, then the animal cap will express mesodermal markers. If no inducing molecule is present, or if present at low concentrations, then the animal cap will develop as epidermis.

Of the first 60 pools screened, 4 pools had potential mesoderm-inducing activity. One pool was split into subpools of 200 colonies and reassayed. Subsequently active pools were split into smaller pools and reassayed until a single active clone was identified. This clone was used to isolate a full-length cDNA from the original ES cell library.

Sequence analysis (GenBank accession no. U60530) showed the isolated clone is $65 \%$ identical at the amino acid level to Drosophila Mad (Sekelsky et al. 1995). In addition, Madr2 is $52 \%$ and $45 \%$ identical to the Caenorhabditis elegans Sma- 2 and Sma-3 proteins, respectively (Savage et al. 1996) and is $46 \%$ identical to the human tumor suppresser DPC4 (Hahn et al. 1996). Drosophila Mad and C. elegans sma genes have been shown by genetic analysis to be downstream effectors of the BMP family of TGF $\beta$-like molecules. Xenopus Mad2 (Xmad2) is $99 \%$ identical to mouse Madr2 at the amino acid level (Graff et al. 1996). Interestingly the cDNA we initially cloned encodes a truncated form of Madr2, which lacks the first 183 of 467 amino acids. We assume that this form of Madr2, which we call $M a d r 2(C)$, initiates at a downstream methionine residue (amino acid 241) that is in a favorable context for initiation.

To determine the temporal and spatial expression of $M a d r 2$, in situ hybridization was performed on embryonic day 6.5 (e6.5)-10.5 mouse embryos. With the possible exception of the heart and tail bud, Madr2 is expressed widely at these stages (Fig. 1). This evidence, along with sequence data showing no signal sequence or transmembrane domains, is consistent with a role for Madr2 as a signal transduction component.

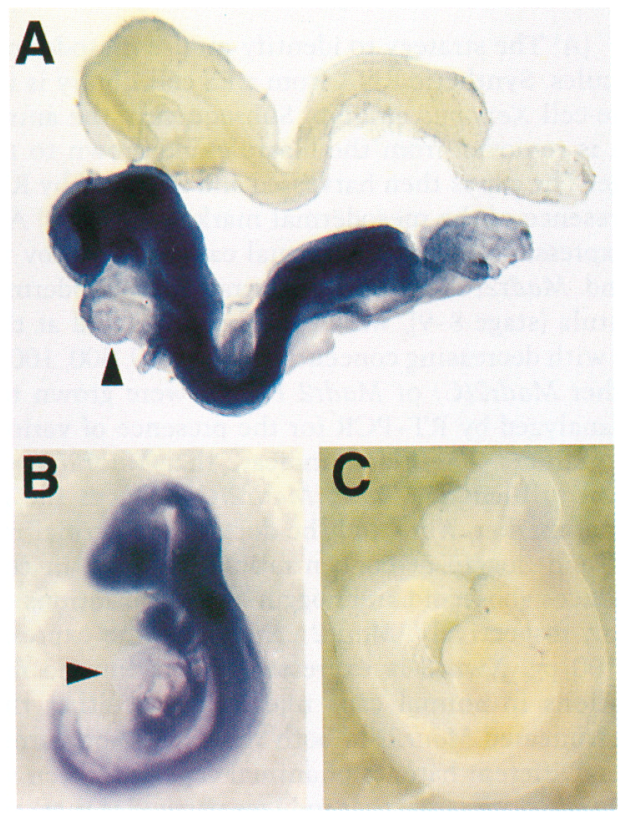

Figure 1. Madr2 expression in mouse embryos. (A) Wholemount in situ hybridization of e8.5 mouse embryos with either sense (top) or antisense (bottom) probes. $(B, C)$ el0.5 mouse embryos hybridized with either antisense $(B)$ or sense $(C)$ Madr2. Arrowheads point to the heart where expression is not detected. 
Madr2 induces dorsal mesoderm in a dose-dependent fashion

The mesoderm-inducing activity of the full length and truncated forms of Madr2 was further assayed to determine what type of mesoderm was being induced. Animal caps explanted from embryos injected with either Madr2 (full length) or Madr2(C) (truncated) were grown to stage 10.5 and assayed by RT-PCR for the expression of several mesodermal markers (Fig. 2B). A quantitative comparison between Madr2 and Madr2(C) demonstrates that the truncated form $M a d r 2(C)$ is more active in inducing a variety of markers than the full-length Madr2. Xbra, a general mesodermal marker is induced by $M a d r 2(C)$ at $50 \mathrm{pg}$ and by Madr2 at $100 \mathrm{pg}$. The organizer-specific dorsal mesodermal markers noggin and goosecoid were
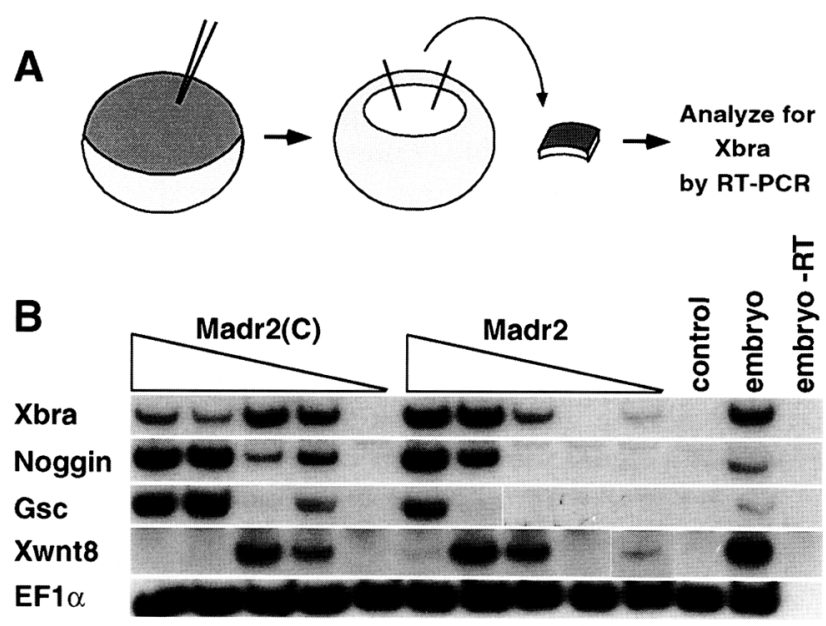

Figure 2. $(A)$ The strategy to identify mouse mesoderm inducing molecules. Synthetic RNA from a ES cell library is injected into a one-cell Xenopus embryo. Subsequently the animal cap ectoderm is removed from the blastula and grown to the gastrula stage. The cap is then harvested and analyzed by RT-PCR for the presence of the mesodermal marker, Xbra. (B) Analysis of gene expression induced in animal cap ectoderm by varying Madr2 and Madr2(C) RNA concentrations. Ectoderm taken from blastula (stage 8-9), which had been injected at the onecell stage with decreasing concentrations $(1000,500,100,50,10$ pg) of either Madr2(C) or Madr2 RNAs, were grown to stage 10.5 and analyzed by RT-PCR for the presence of various mesodermal markers. These data indicate that $M a d r 2(C)$ is more potent than full-length Madr2. Madr2(C) induces the general mesodermal marker, Xbra and the dorsal mesodermal markers goosecoid and noggin at concentrations $>50 \mathrm{pg}$. In contrast, Madr2 induces goosecoid and noggin at concentrations of 1000 and $500 \mathrm{pg}$, respectively. Madr2 can induce the expression of $X b r a$ at $100 \mathrm{pg}$. Xwnt 8 is expressed over a limited range of concentrations in animal caps injected with either the fulllength or truncated Madr2; in both the expression turns off at high doses. Different batches of animal caps have been slightly different in the dose range that induces particular markers. The faint Xbra and Xwnt8 expression in the $10 \mathrm{pg}$ Madr2 lane has not been seen in four other experiments. (Control) Uninjected animal caps; (embryo-RT) whole embryo RNA not treated with reverse transcriptase. EF1- $\alpha$ was used as a control for RNA recovery. both expressed when treated with 50 pg of $\operatorname{Madr2}(C)$. High doses (500-1000 pg) of Madr2 were needed to express these markers. Xwnt 8 , a marker of ventral mesoderm, is induced over a restricted range of doses of both Madr2(C)- and Madr2-injected caps 150-100 and 100$500 \mathrm{pg}$, respectively|. Thus, we conclude that Madr2 is an inducer of dorsal mesoderm and can induce different mesodermal cell types in a dose-dependent manner. These results are similar to those obtained with members of the TGF $\beta$ family, namely nodal and activin (Green et al. 1992; Jones et al. 1995) and to the effects of Xmad2 (Graff et al. 1996).

Morphogenetic movements were observed in Madr2(C)-injected animal caps. Explants recovered from embryos that received $100 \mathrm{pg}$ of $\mathrm{Madr2}(\mathrm{C})$ elongate compared to controls (Fig. 3B,C). At higher concentrations of Madr2(C) the caps also turned inside out, possibly mimicking the involution movements of gastrulation (Fig. 3A). Animal caps injected with high concentrations (1 ng) of Madr2 do not undergo the extensive morphological movements seen in caps injected with $1 \mathrm{ng}$ of Madr2(C). However, these animal caps do elongate. The ability of Madr2 to induce dorsal mesoderm and to induce elongation indicate that Madr2 has activin-like activities, not the bone morphogenetic protein (BMP)-like activity shown in invertebrate Mad homologs (Sekelsky et al. 1995; Savage et al. 1996).

\section{Madr2(C) mRNA injection induces a second axis in host embryos}

The ability of Madr2/C) to specify dorsal mesoderm in ectodermal explants prompted us to see if Madr2 could induce ventral cells of the embryo to adopt a dorsal fate. In multiple experiments, $100 \mathrm{pg}$ of $\operatorname{Madr2}(C)$ was injected into two ventral blastomeres at the four cell stage. Subsequently, the embryos were examined for the formation of a secondary axis. Of embryos injected with $100 \mathrm{pg}$ of Madr2(C) RNA, $82 \%$ developed a partial second axis (Table 1). Madr2 also generates a second axis, albeit less reliably than Madr2(C). Second axes generated by injection of $M a d r 2(C)$ or Madr2 contain neural tissue, muscle and some notochord (Fig. 4 E-G).

Activin also induces a partial second axis in embryos and can induce organizer activity, which recruits neighboring cells into a second axis /Cooke 1989; Thomsen et al. 1990). To address whether Madr2-expressing cells could induce neighboring, nonexpressing cells to form ectopic mesoderm, we traced the fate of Madr2-expressing cells by coinjecting $200 \mathrm{pg}$ of lacZ RNA with $1 \mathrm{ng}$ Madr2(C) RNA or $200 \mathrm{pg}$ of lacZ RNA with $1 \mathrm{ng}$ of Madr2 RNA in two ventral blastomeres of the four-cell embryo. As a control, $200 \mathrm{pg}$ of lacZ RNA was injected in the same manner. The embryos were allowed to grow to the tailbud stage and stained for $\beta$-galactosidase to visualize cells receiving high concentrations of injected mRNA. The results of multiple experiments are included in Table 1 and are shown in Figure 4 (A,B). These results show that cells expressing high amounts of Madr2 are localized to the anterior portion of the second 


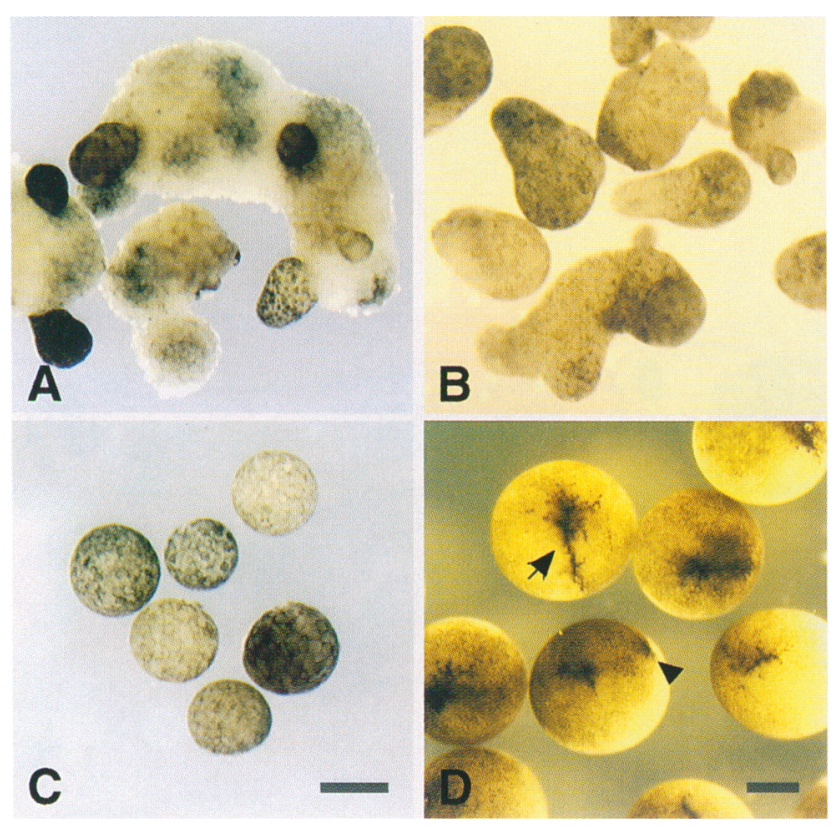

Figure 3. Morphological movements induced by $\operatorname{Madr} 2(\mathrm{C})$ in Xenopus animal caps and embryos. One-cell embryos were injected with $1 \mathrm{ng}(A)$ or $100 \mathrm{pg}(B)$ of $\operatorname{Madr2}(C)$. (A) At high concentrations of $M a d r 2(C)$ (1 ng) animal caps isolated from blastula elongate and turn inside-out so that the cells of the deep layer present on the inside of the cap are now surrounding the pigmented epithelia. (B) At lower concentrations of $M a d r 2(C)(100 \mathrm{pg})$ the caps isolate from injected blastula elongate compared to controls $(C)$. When embryos injected with 500 pg of $M a d r 2(C)$ are allowed to mature to gastrula stage, an ectopic blastopore lip forms at the site of injection $(D)$. The Arrow in $D$ indicates the forming ectopic lip, which is present on the ventral side of the embryo; the arrowhead in $D$ points to the naturally forming dorsal lip. Scale bars, $100 \mu \mathrm{M}(A-C) ; 500 \mu \mathrm{M}$ (D).

axis and suggest that Madr2-expressing cells recruit nonexpressing cells into the second axis. Thus, like activin, Madr2 can induce organizer properties.

In addition, whole embryos injected with Madr2(C) and allowed to develop to gastrulation form a second blastopore lip at the site of injection. Unlike the secondary lip induced by Xwnt-8, which forms ventrally at the same animal-vegetal latitude as the dorsal blastopore, the secondary lip formed by $\operatorname{Madr} 2(\mathrm{C})$ is irregular in shape and forms in the immediate vicinity of injection (Fig. 3D). Similar results have been shown in ectopic lips induced by activin injection (Sokol et al. 1991).

To determine the effect of Madr2 on morphogenetic movements, we injected $1 \mathrm{ng}$ of $\mathrm{Madr2(C)}$ RNA with 200 pg of lacZ RNA tracer into dorsal blastomeres (Fig. 4C,D). Similar to injection of goosecoid RNA (Niehrs et al. 19931, Madr2 causes cells to move to the leading edge of the involuting mesendodermal mantle, eventually populating the leading edge endoderm region of liver diverticulum and pharyngeal endoderm ( 29 of 30 embryos). This result supports the idea that high doses of mesoderm inducers can induce the crawling morphogenetic movements of the leading edge of mesendoderm (Symes et al. 1994).

\section{Madr2 becomes nuclear localized in response to activin signaling}

Because Madr2 appears to be widely expressed in the mouse embryo, contains no signal sequence and is homologous to genes presumed to be involved in the TGF $\beta$ signal transduction pathway, it seems likely that Madr2 is a cytoplasmic protein. To determine the intracellular localization of the Madr2 protein, we made fusion proteins between lacZ and Madr2 and also lacZ and Madr2(C). Both fusion proteins were tested for function in two ways. First, animal caps injected with $1 \mathrm{ng}$ of either lacZ/Madr2 or lacZ/Madr2(C) effectively induced the same markers as Madr2 and Madr2/C). Second, $0.5 \mathrm{ng}$ of $1 a c Z / M a d r 2$ and $1 a c Z / M a d r 2$ (C) RNA were capable of inducing second axes in $80 \%$ and $74 \%$, respectively, of embryos injected (data not shown). In either assay $\operatorname{lacZ} / \mathrm{Madr} 2(\mathrm{C})$ was more potent than $\operatorname{Madr} 2(\mathrm{C})$ : $1 a c Z / M a d r 2$ reproducibly induced Xbra in animal caps at $10 \mathrm{pg}$ and frequently induced head structures (Fig. 4E). Therefore these two criteria show the lac $Z$ fusion proteins retain their biological activity and provide confidence that the lac $Z$ activity will reflect the subcellular location of the active protein.

The embryos generated by ventral injections of the lacZ/Madr2 mRNAs were stained with X-gal to assay for the presence of $\beta$-galactosidase (Fig. 5). The results were similar to those obtained with $l a c Z$ and $M a d r 2$ RNA injections in that expression was predominantly in the anterior cells of the second axis. Interestingly when injected with $1 a c Z / M a d r 2$, the stain in the anterior cells of the second axis was exclusively confined to the nucleus, suggesting that Madr2 is a nuclear protein (Fig. 5A). However, the fusion proteins were not nuclear in all cell

Table 1. Madr2 can induce a second axis

\begin{tabular}{lccc}
\hline Injection & $n$ & $\begin{array}{l}\text { Number of } \\
\text { second axis } \\
\text { induced }\end{array}$ & $\begin{array}{l}\text { Expressing cells } \\
\text { in anterior of } \\
\text { second axis }\end{array}$ \\
\hline none & 116 & 0 & N.A. \\
Madr2 $\langle C\rangle$ & 92 & 76 & N.A. \\
Madr2 & 74 & 21 & N.A. \\
none & 60 & 0 & N.A. \\
Madr2 $(C)$ and $l a c Z$ & 56 & 53 & 40 \\
none & 15 & 0 & 0 \\
Madr2 and lacZ & 20 & 18 & 15 \\
\hline
\end{tabular}

Embryos were injected with $100 \mathrm{pg}$ of $\mathrm{Madr2(C)}$, with $1 \mathrm{ng}$ of Madr2, and with $0.2 \mathrm{ng}$ of $l a c Z$ and $1 \mathrm{ng}$ of either Madr2(C) or $M a d r 2$ into two ventral blastomeres at the four-cell stage. They were allowed to develop and then assayed for the presence of a second axis. If injected with $1 a c Z$, the embryos were subsequently stained for $\beta$-gal. Data are summarized from several experiments. The effectiveness of Madr2 in secondary axis induction varies, as illustrated by the difference between Madr2 and the Madr2 + lacZ mixture. 
Figure 4. Lineage tracing of $M a d r 2(C)$-expressing cells in either dorsal or ventrally injected embryos. We injected dorsal or ventral blastomeres of the four-cell embryo with either lac $Z$ alone $(B, D)$ or coinjected with $M a d r 2(C)$ and lacZ RNA $(A, C)$. Embryos were allowed to develop to stage 35 and were stained with X-gal. $(A)$ Embryos coinjected into ventral blastomeres with 1 ng Madr2(C) and $200 \mathrm{pg} l a c Z$ developed a partial second axis and show Madr2(C) expressing cells to be localized to the anterior portion of the second axis. $(B)$ Control embryos injected ventrally with $200 \mathrm{pg}$ of lacZ. (C) Embryos injected dorsally with 1 $\mathrm{ng}$ of $\mathrm{Madr2}(\mathrm{C})$ and $200 \mathrm{pg}$ of $l a c Z$, showing the expressing cells in the anterior endoderm. (D) Control embryos injected dorsally with $200 \mathrm{pg}$ of $l a c Z$. Comparison of Madr2(C)-injected embryos $(A, C)$ with lac $Z$ controls $(B, D)$ demonstrate the ability of Madr2 to change the prospective fate of ventral and dorsal cell types. Immunostaining of axes generated by injecting $500 \mathrm{pg}$ of lacZ/Madr2(C) (E), $500 \mathrm{pg}$ of Madr2 (F), and $500 \mathrm{pg}$ of $l a c Z / M a d r 2(G)$ into ventral blastomeres. Embryos were stained with 6F1 $1(E)$, a neural specific $\mathrm{mAb}$; Tor $70(F)$, a notochord specific $\mathrm{mAb}$; and $12101(G)$, a muscle specific $\mathrm{mAb}$. Higher magnification shows that the notochord cells are not well organized, and the Tor 70 antigen is deposited around individual cells rather than in an organized notochord sheath. Tor70 also stains the otic vesicle, which can be seen rostral to the notochord in the second axis. In each panel arrowheads indicate the induced axis. The neural staining in $E$ shows that eyes are induced in the second axis by lacZ/Madr2(C). The eyes in the second axis contained pigmented retina that was bleached after immunostaining.
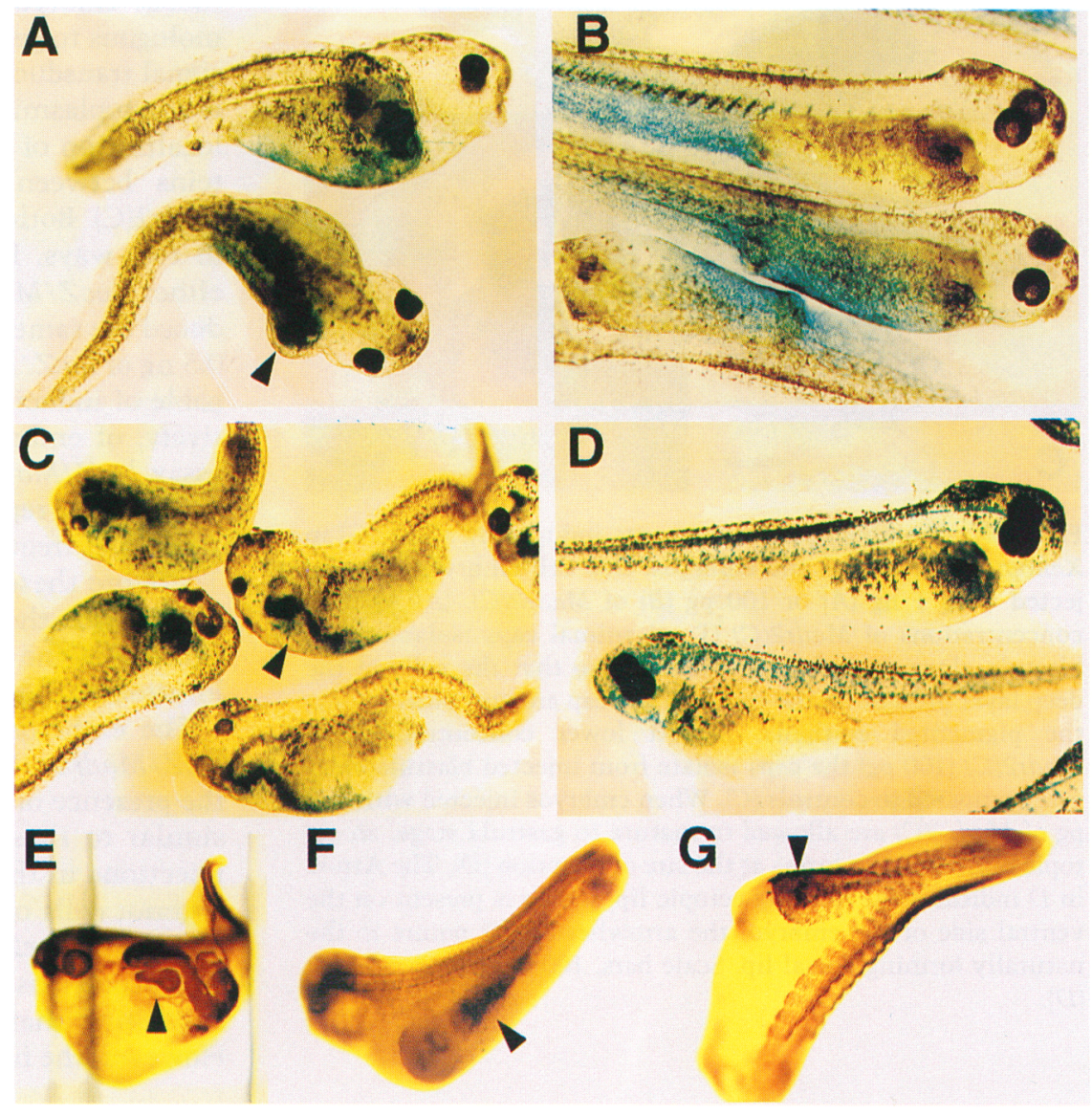

types. Expression of the fusion was cytoplasmic in epidermal cells as well as cells in the posterior of the embryo (Fig. 5B). This suggests that when Madr2 is in the correct embryonic context to respond to mesoderm-inducing signals, it sensitizes the cells to these signals and induces a dorso-anterior fate. This may then cause a positive feedback loop of nuclear localization and dorsoanterior gene transcription. When Madr2-expressing cells receive an insufficient signal to establish an initial dorso-anterior fate, the Madr2 protein remains cytoplasmic and the expressing cells adopt epidermal, or posterior fates.

To more rigorously test the extent to which $1 a c Z$ / Madr2 is localized to the nucleus, we excised animal caps from stage 8 embryos injected with $0.5 \mathrm{ng}$ of $1 \mathrm{acZ} /$ $M a d r 2$. The caps were aged to stage 12 , fixed, stained with X-gal and bisbenzamide, and mechanically disrupted. In this ectodermal context, lacZ/Madr2 is expressed throughout the cell and is never seen exclusively in the nucleus (Fig 5C,D). This confirms that in the absence of marginal zone (mesodermal) signals, Madr2 remains predominantly cytoplasmic. Because the overexpression phenotypes of Madr2 are strikingly similar to those of the TGF $\beta$ molecules activin and nodal (Thomsen et al. 1990; Jones et al. 19951, Madr2 could be a signal transduction component in either of these pathways. Thus, either of these molecules seemed likely to function as the signal which stimulates Madr2 to enter the nucleus. Therefore, we analyzed animal caps excised from one-cell embryos in which $0.5 \mathrm{ng}$ of $1 \mathrm{acZ} / \mathrm{Madr} 2$ RNA was coinjected with either $0.1 \mathrm{ng}$ of human activin $\beta B$ RNA or $0.5 \mathrm{ng}$ nodal RNA. In our hands, this nodal mRNA has similar effects to activin, but a lower activity; nodal appeared to have no effect on the localization of $1 a c Z / M a d r 2$ in the cells. In contrast, activin enhanced the transport of lacZ/Madr2 into the nucleus (Fig. 5E,F). Furthermore, coinjection of activin and the dominantnegative activin receptor blocks the nuclear transloca- 

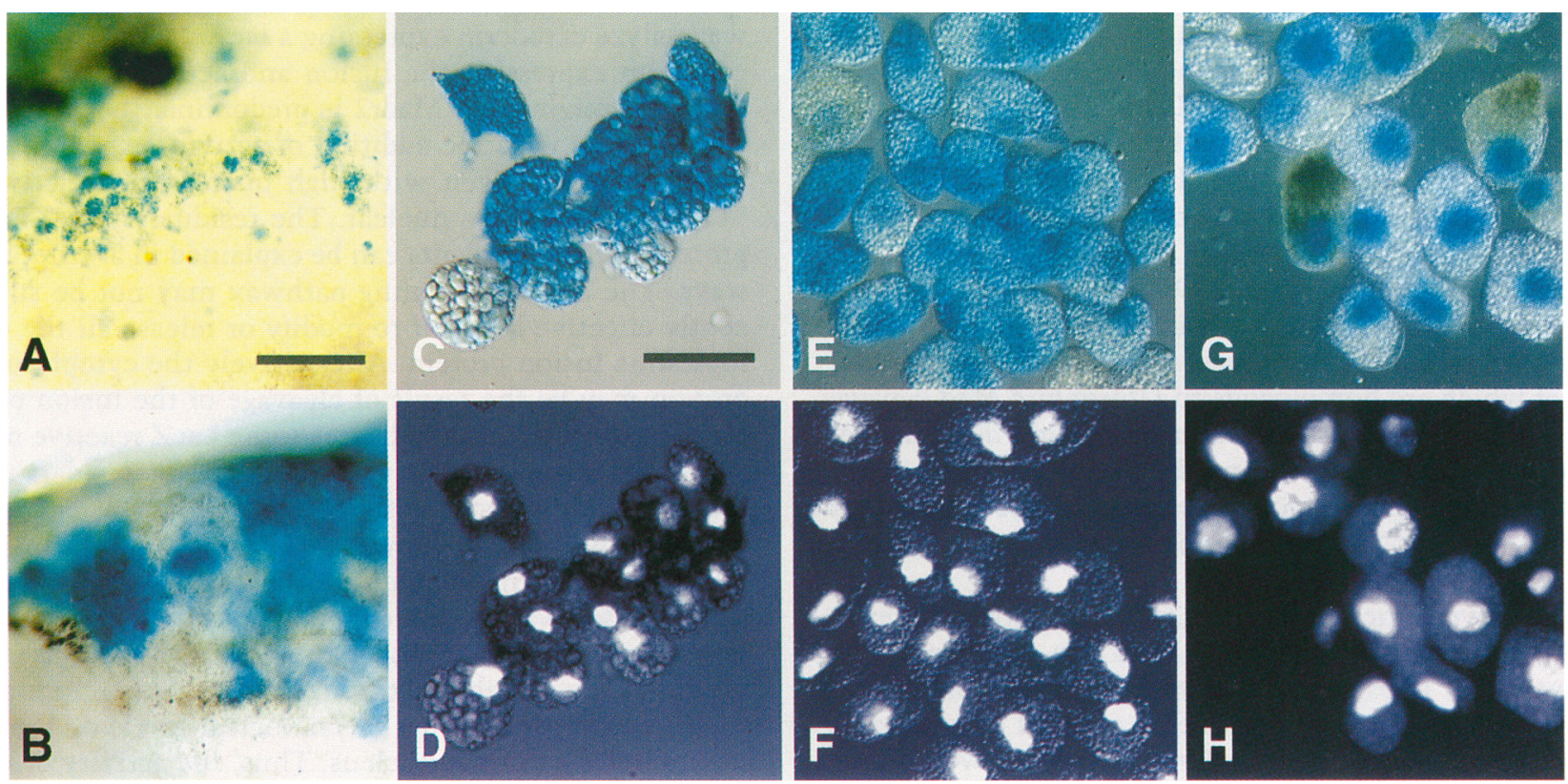

Figure 5. Nuclear localization of the Madr2 and Madr2/C $)$ proteins. $(A, B) 0.5 \mathrm{ng}$ of lacZ/Madr2 RNA was injected into the two ventral blastomeres at the four-cell stage. Embryos were allowed to develop until stage 35 and were subsequently stained with X-gal. Madr2 protein present in the anterior of the second axis was localized to the nucleus $(A)$, whereas Madr2 protein present in the epidermis was cytoplasmically localized (B). $0.5 \mathrm{ng}$ of the full-length fusion lacZ/Madr2 RNA, $0.5 \mathrm{ng}$ of the truncated fusion lacZ/Madr2(C) RNA, or $0.5 \mathrm{ng}$ of the full-length fusion lacZ/Madr2 and $0.1 \mathrm{ng}$ of activin $\beta B$ was injected into the animal pole of the one-cell embryo. At the blastula stage (8-9) animal caps were explanted, grown to gastrula stage $(10.5)$, and stained with X-gal to assay for the presence of $\beta$-galactosidase $(C, E, G)$ and bisbenzamide to accurately identify nuclei $(D, F, H)$. LacZ/Madr2 full-length protein was expressed ubiq uitously throughout the cells $(C, D)$. When exposed to activin $\beta B$, lacZ/Madr2 was predominantly nuclear localized $(E, F)$. Interestingly, the truncated fusion protein lac $Z / M a d r 2(C)$ was localized only in the nucleus $(G, H)$ with or without the addition of activin. Scale bars, $100 \mu \mathrm{M}(A, B), 50 \mu \mathrm{M}(C-G)$.

tion of Madr2 in response to activin (data not shown). In most cells, the addition of activin was not enough to ensure complete nuclear localization. This cannot be attributed to a weak activin signal, because this dose of activin is 100 -fold higher than the optimal dose for Xbra induction (Graff et al. 1994; D. Hsu, pers. comm.) and causes death in embryos because of excessive gastrulation movements.

To determine whether the truncated $\operatorname{Madr} 2(\mathrm{C})$ can also respond to activin signaling, we subsequently assayed the subcellular location of a lacZ/Madr2 (C) fusion after expression in animal caps. Interestingly, lacZ/ Madr2 $(\mathrm{C})$ is localized to the nucleus in every expressing cell, even in the absence of activin (Fig. 5G,H). This suggests that the amino-terminal domain of the full-length protein is required for regulating entry into the nucleus. We suggest that upon the addition of activin, the signal transduction pathway is activated and either stimulates removal of a cytoplasmic retention activity, or causes refolding of the protein to expose a cryptic nuclear localization signal. Thus, the amino-terminus of the protein is likely to be regulatory, and the carboxy-terminus acts in the nucleus to activate downstream signals.

The activin-induced nuclear localization coupled with the activin-like induction of mesodermal gene expres- sion strongly suggest that Madr2 is a member of the activin or activin-like signal transduction pathway.

\section{Discussion}

\section{Mad proteins can be Bmp or activin-like signaling molecules}

The TGF $\beta$ family of signaling molecules has been shown to be important in a wide range of developmental phenomena. During embryogenesis in vertebrates, members are needed to set up the body plan, to control the formation of limbs, cartilage and bone and to induce the formation of mesoderm (Lyons et al. 1991; Kingsley 1994). In addition, changes in the activities of these molecules have been implicated in the onset of several diseases, including fibrosis and cancer (Roberts and Sporn 1993).

The signaling effects of the TGF $\beta$ family are mediated by transmembrane serine threonine kinase receptors, which are represented in two classes, type I and type II (Kingsley 1994). The type II receptors appear to be constitutively active. Upon ligand binding, a heteromeric complex forms and the type II receptor activates the type I receptor by phosphorylation (Wrana et al. 1994). The events triggered by the activation of the type I recep- 
tor are beginning to be elucidated (Massagué 1996). Genetic screens in Drosophila and C. elegans have uncovered molecules that seem to play important roles in the signal transduction pathway of the BMP subclass of the TGF $\beta$ superfamily. A screen looking for dominant enhancers of a imaginal disk phenotype caused by lack of $d p p$, the Drosophila homolog of Bmp2/4, revealed the gene Mad (Sekelsky et al. 1995). Similar screens in $C$. elegans for genes acting downstream of daf-4, a BMP-like receptor, revealed three genes, sma-2, sma-3, and sma-4, all of which are homologous to Drosophila Mad (Savage et al. 1996). It was shown that sma-2 and daf-4 are required in the same cells and, in addition, expression of daf- 4 cannot rescue sma-2 mutations. This suggests that the C. elegans sma genes are involved in a BMP-like signal transduction pathway.

In a novel functional screen, we have cloned a vertebrate Mad homolog, Madr2. Madr2 is $65 \%$ and $52 \%$ identical to Drosophila Mad and C. elegans Sma-2, respectively. Because these proteins are well conserved, it would be a logical assumption that Madr2 would also function as a BMP signal transduction molecule. However, the Madr2 overexpression phenotypes are not similar to those of BMP4, which is a ventral mesoderm inducer (for review, see Harland 1994). Instead the activities of Madr2 are strikingly similar to another TGF $\beta$ molecule, activin, which is a dorsal mesoderm inducer (Green and Smith 1990; Thomsen et al. 1990). Recently other vertebrate homologs of Drosophila Mad and C. elegans sma-2 and -3 have been cloned based upon their sequence similarities /Graff et al. 1996; Hoodless et al. 1996; Thomsen 1996). Xenopus madl and mad2 (Xmadl, Xmad2), which are $62 \%$ identical, produce distinctly different responses in embryos: Xmadl induces ventral mesoderm, whereas Xmad2 induces dorsal mesoderm /Graff et al. 1996; Thomsen 1996). In this study we have provided evidence that the addition of activin stimulates the transport of full-length Madr2 protein into the nucleus, demonstrating that Madr2 responds to the activin signaling. Similar results have been obtained for BMPdependent nuclear translocation of Madrl (Hoodless et al. 1996; Liu et al. 1996). Therefore, there may be a Mad protein or set of proteins for each TGF $\beta$ pathway, whether BMP- or activin-like. Interestingly many of the TGF $\beta$ superfamily ligands bind the same receptors, and yet result in different responses. It seems likely that the biological response to members of the superfamily will result not only from the affinity of the ligand for different receptor combinations, but may also result from integration of the signal at the level of the transducing Mad-related proteins.

\section{Nuclear localization of Madr2 and Madr2(C) in response to activin}

We have shown that Madr2 is localized to the nucleus in vivo in response to endogenous signals located at the anterior portion of a second axis. We infer that this signal is an activin-like molecule from experiments where we analyze ectoderm expressing a lacZ/Madr2 fusion or ectoderm expressing the fusion and activin. In the absence of activin lacZ/Madr2 is predominantly cytoplasmic whereas with the addition of activin, expression is mostly nuclear. Even with high quantities of activin, Madr2 is not always nuclear. The residual cytoplasmic protein in these explants can be explained in a variety of ways. The activin signaling pathway may not be sufficently effective by itself to modify or release all the cytoplasmic fusion protein. Alternatively the cytoplasmic protein may be the result of cleavage of the fusion protein; Western blotting indicates some Lac $Z$ reactive material that is smaller than the full-length fusion /data not shown). Even without activin signaling, the full-length Madr2 molecule can function to induce mesoderm in Xenopus ectoderm. When the localization of full-length LacZ/Madr2 was examined, a large amount of mRNA was injected $(500 \mathrm{pg})$. Under these conditions, the protein is evenly distributed throughout the cell. Currently, we do not know whether physiological levels of Madr2 are excluded from the nucleus. Thus, the activity of the full-length Madr2 in injection experiments could be attributed to overwhelming the cytoplasmic retention machinery, eventually leading to the induction of mesoderm.

All Mad homologs discovered thus far contain conserved amino-terminal and carboxy-terminal domains with a variable proline-rich intervening region. $\operatorname{Madr} 2(\mathrm{C})$ gives us a glimpse at the importance of these two conserved regions. It appears that the amino-terminal region is not required for signaling, but may regulate activity by acting as a cytoplasmic tether. A precedent for this type of mechanism has been studied extensively in the transcription factor dorsal, which is required to direct the development of ventral structures in the fly (Morisato and Anderson 1995), and NF- $\mathrm{BB}$, which is involved in the activation of $\kappa$ chain gene transcription in B lymphocytes (Verma et al. 1995). Before activation, dorsal is held in the cytoplasm through an association with cactus. When dorsal receives a signal from the receptor toll, dorsal is freed from the cactus protein and enters the nucleus. NF- $\kappa \mathrm{B}$ is similarly anchored in the cytoplasm by the protein I- $\mathrm{KB}$. In the case of Mad proteins, a cytoplasmic tether could be binding to the conserved amino-terminal domain of Madr2, anchoring the protein in the cytoplasm. When the amino-terminal region is deleted [as in Madr2(C)] the cytoplasmic protein would no longer sequester Madr2 and allow it to be freely transported to the nucleus. The observation that $\mathrm{Madr} / \mathrm{C})$ is confined to the nucleus as well as the finding that $\operatorname{Madr} 2(\mathrm{C})$ is more active than Madr2 are consistent with this model. Fusion to lacZ increases the activity further, perhaps by providing stability, or more efficient translation. In the case of full-length Madr2 the activated receptor could disrupt the Mad/tether complex and allow the fulllength molecule to accumulate in the nucleus.

An alternate mechanism for nuclear localization is exemplified by Signal Transducer and Activator of Transcription (STATs). Upon activation of cytokine receptors, the STATs are phosphorylated, dimerize, and a 
cryptic nuclear localization signal is exposed, allowing translocation and activity (Karin and Hunter 1995).

What Madr2 does once it enters the nucleus is still unknown. The Mad homolog Smadl/Madrl does have transcriptional activation activity, which is dependent upon BMP signaling. This transcriptional activating activity resides in the carboxy-terminal domain, consistent with the activity observed for Madr2/C) (Liu et al. 1996).

Our screen for mouse mesoderm inducers has exploited the relatively easy assays that can be carried out in Xenopus. It remains to be determined to what extent Madr2 plays a role in the development of mesoderm in the mouse. Several TGF $\beta$ family members have been shown to be important in early gastrulation in the mouse, including $B m p 4, B m p r 1 A$, and nodal. Mice lacking BmprlA do not form mesoderm, whereas mice lacking $B m p 4$, which can signal through $B m p r 1 A$, have a variable phenotype (Mishina et al. 1995; Winnier et al. 1995). Although many Bmp4 homozygous embryos do not survive past gastrula stages, some can develop to the headfold stage. In addition, mutations are being studied that have defects in mesoderm formation. The eed mutant fails to gastrulate normally and generates little mesoderm whereas embryos mutant for the msd locus do not produce mesoderm. The molecular lesion in the eed or the msd genes have not been reported (Holdener et al. 1994; Faust et al. 1995).

Previous functional screens have assayed for axis formation, either in ventralized embryos or on the ventral side of normal embryos (Smith and Harland 1991, 1992; Lemaire et al. 1995; Smith et al. 1995). Such assays have previously revealed molecules that pattern the mesoderm, but have no intrinsic mesoderm-inducing ability. The current screen was more specific, in that it assayed for Xbra induction and therefore for mesoderm induction. However, the animal cap assay can be adapted to screen for components of the wnt signaling pathway, which activate Xnr-3 expression (Smith et al. 1995), or for activities that antagonize BMP signals, which result in neural induction and activation of neural cell adhesion molecule (NCAM) and $n r p-1$ (Lamb et al. 1993; Knecht et al. 1995; Sasai et al. 1995; Wilson and Hemmati-Brivanlou 1995). Signal transduction components are usually less active than ligands in such assays, but if small pools of cDNAs are screened, even weak activities should be identifiable. We therefore expect that further screens will allow us to identify additional secreted signaling molecules and intracellular signal transduction components.

\section{Materials and methods \\ Growth of ES cell and isolation of RNA}

CCE ES cells were grown on LIF-transfected STO feeder layers (Robertson 1987) in Dulbecco's modified Eagle medium containing $10 \%$ fetal calf serum, $10 \%$ newborn calf serum, and 0.1 $\mathrm{mM} \beta$-mercaptoethanol at $37^{\circ} \mathrm{C}$ in $5 \% \mathrm{CO}_{2}$. To induce differentiation, the STO feeder layers were removed by washing $80 \%$ confluent plates in $1 \times$ PBS, trypsinized, and then transferred in medium to tissue culture plates, that had been treated with
$0.1 \%$ gelatin. The STO cells were allowed to adhere to the gelatinized plates for $30 \mathrm{~min}$ at $37^{\circ} \mathrm{C}$. Subsequently, the medium, containing mostly ES cells, was transferred to new gelatinized plates and the procedure repeated to ensure removal of all STO cells. The density of ES cells in the medium was analyzed with a hematocytometer and cells were plated at a density of $9 \times 10^{6}$ cells per $10-\mathrm{cm}$ gelatinized plate. These cells were cultured for $24 \mathrm{hr}$ at $37^{\circ} \mathrm{C}$. At this time, twelve $80 \%$ confluent plates were harvested by the acid phenol extraction method (Chomczynski and Sacchi 1987). Poly(A) ${ }^{+}$RNA was isolated by the PolyTract isolation system (GIBCO-BRL).

\section{Construction of cDNA library}

The ES cDNA library was constructed in a modified pCS2 vector (Turner and Weintraub 1994). pCS105 (gift of D. Hsu) was modified to allow directional cloning using the Superscript plasmid system (GIBCO-BRL). The ligated cDNAs were used to transform DH10B cells (GIBCO-BRL). The resulting library contained 225,000 clones. Subsequently 100,000 of these clones were plated at a density of 1000 colonies per $97-\mathrm{mm}$ plate. Of 20 randomly chosen plasmids, all had inserts which ranged from 0.6 to $3.0 \mathrm{~kb}$. The average insert size was $1.6 \mathrm{~kb}$. Each plate was harvested by adding $3 \mathrm{ml}$ of LB and scraping the cells. An amount of $0.5 \mathrm{ml}$ of this culture was frozen by adding glycerol to $30 \%$. Plasmid DNA was isolated by the alkaline lysis method from the remaining $2.5 \mathrm{ml}$.

In vitro transcription and $R T-P C R$

Pooled plasmid DNA was linearized with AscI. Capped mRNA was made from the pooled plasmid DNA with SP6 RNA polymerase using message machine (Ambion). By injecting $10 \mathrm{nl}$ of a $1 \mathrm{mg} / \mathrm{ml}$ dilution of RNA, $10 \mathrm{ng}$ was introduced into the animal pole of the one cell Xenopus embryo. Animal caps were explanted from these injected embryos at blastula stage $(8-9)$, and grown to gastrula stage (10.5). RNA from the caps was either harvested as described (Condie and Harland 1987) and subsequently digested with DNase to remove genomic DNA (Wilson and Melton 1994) or harvested using Trizol (GIBCO-BRL). RT-PCR was performed as described (Wilson and Melton 1994). Primer sets for analysis of Xbra, Ef1a, goosecoid, noggin, and muscle actin are described by Wilson and Melton (1994). Xnot primers were designed by F. Mariani (University of California, Berkeley): Upstream (U)-5'-ATCTATGCCCTACCGCTA-3' (nucleotides 671-688) and Downstream (D)-5'-CA-GTGGGAGAATGGCAAT-3' (nucleotides 845-827).

\section{LacZ/Madr2 fusion proteins}

Primers were made to introduce EcoRI sites at the ends of either Madr2 or Madr2(C). The upstream Madr2 primer begins with EcoRI and BglII restriction sites, has a few base pairs to maintain frame and then concludes with Madr2 sequence beginning $7 \mathrm{bp}$ upstream of the ATG. The upstream Madr2(C) primer is arranged in the same way, but concludes with $\operatorname{Madr} 2(\mathrm{C})$ sequence beginning $6 \mathrm{bp}$ from the ATG from which it is presumed to initiate. The downstream primer was the same for both Madr2 and $M a d r 2(C)$. The downstream primer has an EcoRI site on the 5 ' end, the final 9 amino acids and the stop codon of the Madr2 protein. Madr2 U-5'-(GGAATTCATCGAGATCTAAGAAAATGTCGTCCATCTTGCCATTCACTCCG-3'); Madr2(C) U-(5'GGAATTCATCGAGATCTCAAAGTATGGACACAGGCTCTCCGGCTGAA-3'); D-(5'-CGGAATTCTTACGACATGCTTGAGCATCGCACTGAAGG-3'). The Madr2 fragments were amplified with Taq using PCR $\left(1 \mathrm{~min}\right.$ at $94^{\circ} \mathrm{C}, 1 \mathrm{~min}$ at $60^{\circ} \mathrm{C}$ and 
1.5 min at $72^{\circ} \mathrm{C}$ for 20 cycles|, digested with EcoRI and cloned into the EcoRI site downstream of the lac $Z$ gene in $\mathrm{pCS}^{+} \mathrm{cyt} \beta$ gal, constructed by D. Turner, R. Rupp, J. Lee, and H. Weintraub (Fred Hutchinson Cancer Research Center, Seattle, WA). The fusion proteins resulting from the expression of these constructs should initiate at the AUG present in $\beta$-galactosidase and terminate at the Madr2 stop codon. $\beta$-Galactosidase protein was visualized using X-gal (Sanes et al. 1986).

\section{In situ hybridization and immunostaining}

Whole-mount in situ hybridization was performed according to the protocol described by D. Wilkinson (1992). In three separate experiments sense and antisense probes were generated from Madr2(C), and a probe for antisense Brachyury (Hermann et al. 1990) was used as a positive control. The presence of neural tissue, muscle and notochord in whole Xenopus embryos was determined by immunostaining with the antibodies 6F11 |Lamb et al. 1993), 12101 (Kintner and Brockes 1984), and Tor70 (Bolce et al. 1992), respectively.

\section{Acknowledgments}

We thank the members of the Harland laboratory for critical reading of this manuscript; Rosa Beddington for advice and encouragement; Lisa Brunet for coping with the mice; and Wenge Zhang for technical expertise. We thank Joan Massagué, Jonathan Graff, and Gerry Thomsen for communicating results prior to publication. This work was supported by National Institutes of Health grant GM 42341. J.C.B is a fellow of The Jane Coffin Childs Memorial Fund for Medical Research. This investigation has been aided by a grant from the Jane Coffin Childs Memorial Fund for Medical Research.

The publication costs of this article were defrayed in part by payment of page charges. This article must therefore be hereby marked "advertisement" in accordance with 18 USC section 1734 solely to indicate this fact.

\section{References}

Amaya, E., T.J. Musci, and M.W. Kirschner. 1991. Expression of a dominant negative mutant of the FGF receptor disrupts mesoderm formation in Xenopus embryos. Cell 66: 257270.

Beddington, R.S. and E.J. Robertson. 1989. An assessment of the developmental potential of embryonic stem cells in the midgestation mouse embryo. Development 105: 733-737.

Bolce, M.E., A. Hemmati-Brivanlou, P.D. Kushner, and R.M. Harland. 1992. Ventral ectoderm of Xenopus forms neural tissue, including hindbrain, in response to activin. Development 115: 681-688.

Chomczynski, P. and N. Sacchi. 1987. Single-step method of RNA isolation by acid guanidinium thiocyanate-phenolchloroform extraction. Anal. Biochem. 162: 156-159.

Condie, B.G. and R.M. Harland. 1987. Posterior expression of a homeobox gene in early Xenopus embryos. Development 101: 93-105.

Conlon, F.L., K.S. Barth, and E.J. Robertson. 1991. A novel retrovirally induced embryonic lethal mutation in the mouse: Assessment of the developmental fate of embryonic stem cells homozygous for the 413.d proviral integration. Development 111: 969-981.

Conlon, F.L., K.M. Lyons, N. Takaesu, K.S. Barth, A. Kispert, B. Herrmann, and E.J. Robertson. 1994. A primary requirement for nodal in the formation and maintenance of the primitive streak in the mouse. Development 120: 1919-1928.
Cooke, J. 1989. Mesoderm-inducing factors and Spemann's organizer phenomenon in amphibian development. Development 107: 229-241.

Deng, C.X., A. Wynshaw-Boris, M.M. Shen, C. Daugherty, D.M. Ornitz, and P. Leder. 1994. Murine FGFR-1 is required for early postimplantation growth and axial organization. Genes \& Dev. 8: 3045-3057.

Faust, C., A. Schumach, B. Holdener, and T. Magnuson. 1995. The eed mutation disrupts anterior mesoderm production in mice. Development 121: 273-285.

Feldman, B., W. Poueymirou, V.E. Papaioannou, T.M. DeChiara, and M. Goldfarb. 1995. Requirement of FGF-4 for postimplantation mouse development. Science 267: 246-249.

Graff, J.M., R.S. Thies, J.J. Song, A.J. Celeste, and D.A. Melton. 1994. Studies with a Xenopus BMP receptor suggest that ventral mesoderm-inducing signals overide dorsal signals in vivo. Cell 79: 169-179.

Graff, J.M., A. Bansal, and D.A. Melton. 1996. Xenopus mad proteins transduce distinct subsets of signals for the TGF $\beta$ superfamily. Cell 85: 479-487.

Green, J.B.A. and J.C. Smith. 1990. Graded changes in dose of a Xenopus activin A homologue elicit stepwise transitions in embryonic cell fate. Nature 347: 391-394.

Green, J.B., H.V. New, and I.C. Smith. 1992. Responses of embryonic Xenopus cells to activin and FGF are separated by multiple dose thresholds and correspond to distinct axes of the mesoderm. Cell 71: 731-739.

Hahn, S.A., M. Schutte, A.T. Hoque, C.A. Moskaluk, L.T. da Costa, E. Rozenblum, C.L. Weinstein, A. Fischer, C.J. Yeo, R.H. Hruban, and S.E. Kern. 1996. DPC4, a candidate tumor suppressor gene at human chromosome 18q21.1. Science 271: 350-353.

Harland, R.M. 1994. The transforming growth factor $\beta$ family and induction of the vertebrate mesoderm: Bone morphogenetic proteins are ventral inducers. Proc. Natl. Acad. Sci. 91: 10243-10246.

Hemmati-Brivanlou, A. and D.A. Melton. 1992. A truncated activin receptor inhibits mesoderm induction and formation of axial structures in Xenopus embryos. Nature 359: 609614.

Herrmann, B.G., S. Labeit, A. Poustka, T.R. King, and H. Lehrach. 1990. Cloning of the $\mathrm{T}$ gene required in mesoderm formation in the mouse. Nature 343: 617-622.

Hogan, B., R. Beddington, F. Costantini, and E. Lacy. 1994. Manipulating the mouse embryo: A laboratory manual (2nd ed.). Cold Spring Harbor Laboratory Press, Cold Spring Harbor, NY.

Holdener, B.C., C. Faust, N.S. Rosenthal, and T. Magnuson. 1994. msd is required for mesoderm induction in mice. Development 120: 1335-1346.

Hoodless, P.A., T. Haerry, S. Abdollah, M. Stapleton, M.B. O'Connor, L. Attisano, and J.L. Wrana. 1996. Madr1, a MADrelated protein that functions in BMP2 signaling pathways. Cell 85: 489-500.

Johansson, B.M. and M.V. Wiles. 1995. Evidence for involvement of activin A and Bone Morphogenic Protein 4 in mammalian mesoderm and haematopoietic development. Mol. Cell. Biol. 15: 141-151.

Jones, C.M., M.R. Kuehn, B.L. Hogan, J.C. Smith, and C.V. Wright. 1995. Nodal-related signals induce axial mesoderm and dorsalize mesoderm during gastrulation. Development 121: 3651-3662.

Karin, M. and T. Hunter. 1995. Transcriptional control by protein phosphorylation: Signal transmission from the cell surface to the nucleus. Curr. Biol. 5: 747-757.

Kessler, D.S. and D.A. Melton. 1994. Vertebrate embryonic in- 
duction-mesodermal and neural patterning. Science 266: 596-604.

Kingsley, D.M. 1994. The TGF- $\beta$ superfamily: New members, new receptors, and new genetic tests of fuction in different organisms. Genes \& Dev. 8: 133-146.

Kintner, C.R. and Brockes, J.P. 1984. Monoclonal antibodies identify blastema cells derived from differentiating muscle in newt limb regeneration. Nature 308: 67-69.

Knecht, A.K., P.J. Good, I.B. Dawid, and R.M. Harland. 1995. Dorsal-ventral patterning and differentiation of noggin-induced neural tissue in the absence of mesoderm. Development 121: 1927-1936.

Lamb, T.M., A.K. Knecht, W.C. Smith, S.E. Stachel, A.N. Economides, N. Stahl, G.D. Yancopolous, and R.M. Harland. 1993. Neural induction by the secreted polypeptide noggin. Science 262: 713-718.

Lemaire, P., N. Garret, and J.B. Gurdon. 1995. Expression cloning of siamois, a Xenopus homeobox gene expressed in dorsal vegetal cells of blastulae and able to induce a complete secondary axis. Cell 81: 85-94.

Liu, F., A. Hata, J.C. Baker, J. Doody, J. Carcámo, R.M. Harland, and J. Massagué. 1996. Human Smad1, a mediator of BMP signals, is a transcriptional activator. Nature 38: 620-623.

Lyons, K.M., C.M. Jones, and B.L. Hogan. 1991. The DVR gene family in embryonic development. Trends Genet. 7: 408412.

Massagué, J. 1996. TGF $\beta$ signaling: Receptors, transducers and Mad proteins. Cell 85: 947-950.

Mishina, Y., A. Suzuki, N. Ueno, and R.R. Behringer. 1995. Bmpr encodes a type I bone morphogenic protein receptor that is essential for gastrulation during mouse embryogenesis. Genes \& Dev. 9: 3027-3037.

Morisato, D. and K.V. Anderson. 1995. Signaling pathways that establish the dorsal-ventral pattern of the Drosophila embryo. Annu. Rev. Genetics 29: 371-399.

Niehrs, C., R. Keller, K.W. Cho, and E.M. De Robertis. 1993. The homeobox gene goosecoid controls cell migration in Xenopus embryos. Cell 72: 491-503.

Roberts, A.B. and M.B. Sporn. 1993. Physiological actions and clinical applications of transforming growth factor- $\beta$ (TGFB). Growth Factors 8: 1-9.

Robertson, E.J. 1987. Teratocarcinomas and embryonic stem cells: A practical approach. IRL Press, Oxford, UK.

Rupp, R.A., L. Snider, and H. Weintraub. 1994. Xenopus embryos regulate the nuclear localization of XMyoD. Genes \& Dev. 8: 1311-1323.

Sanes, J.R., J.L. Rubenstein, and J.F. Nicolas. 1986. Use of a recombinant retrovirus to study post-implantation cell lineage in mouse embryos. EMBO I. 5: 3133-3142.

Sasai, Y., B. Lu, H. Steinbeisser, and E.M. De Robertis. 1995. Regulation of neural induction by the Chd and Bmp-4 antagonistic patterning signals in Xenopus. Nature 376: 333336.

Savage, C., P. Das, A.L. Finelli, S.R. Townsend, C.Y. Sun, S.E. Baird, and R.W. Padgett. 1996. Caenorhabditis elegans genes sma-2, sma-3, and sma-4 define a conserved family of transforming growth factor beta pathway components. Proc. Natl. Acad. Sci. 93: 790-794.

Sekelsky, I.J., S.J. Newfeld, L.A. Raftery, E.H. Chartoff, and W.M. Gelbart. 1995. Genetic characterization and cloning of mothers against dpp, a gene required for decapentaplegic function in Drosophila melanogaster. Genetics 139: 13471358.

Slack, J.M.W. 1994. Inducing factors in Xenopus early embryos. Curr. Bio. 4: 116-126.

Smith, W.C. and R.M. Harland. 1991. Injected Xwnt-8 RNA acts early in Xenopus embryos to promote formation of a vegetal dorsalizing center. Cell 67: 753-765.

- 1992. Expression cloning of noggin, a new dorsalizing factor localized to the Spemann organizer in Xenopus embryos. Cell 70: 829-840.

Smith, W.C., R. McKendry, S. Ribisi, and R.M. Harland. 1995. A nodal-related gene defines a physical and functional domain within the Spemann organizer. Cell 82: 37-46.

Sokol, S., J.L. Christian, R.T. Moon, and D.A. Melton. 1991. Injected Wnt RNA induces a complete body axis in Xenopus embryos. Cell 67: 741-752.

Symes, K., C. Yordan, and M. Mercola. 1994. Morphological differences in Xenopus embryonic mesodermal cells are specified as an early response to distinct threshold concentrations of activin. Development 120: 2339-2346.

Thomsen, G.H. 1996. Xenopus mothers against decapentaplegic is an embryonic ventralizing agent that acts downstream of the BMP 2/4 receptor. Development 122: 2359-2366.

Thomsen, G., T. Woolf, M. Whitman, S. Sokol, J. Vaughan, W. Vale, and W. Melton. 1990. Activins are expressed early in Xenopus embryogenesis and can induce axial mesoderm and anterior structures. Cell 63: 485-493.

Turner, D.L. and H. Weintraub. 1994. Expression of achaete scute homolog 3 in Xenopus embryos converts ectodermal cells to a neural fate. Genes \& Dev. 8: 1434-1447.

Vassalli, A., M.M. Matzuk, H.A. Gardner, K.F. Lee, and R. Jaenisch. 1994. Activin/inhibin $\beta$ B subunit gene disruption leads to defects in eyelid development and female reproduction. Genes \& Dev. 8: 414-427.

Verma, I.M., K. Stevenson, E.W. Schwarz, D. Van Antwerp, and S. Miyamoto. 1995. Rel-NF-к-B-I-к-B family: Intimate tales of association and dissociation. Genes \& Dev. 9: 2723-2735.

Wilkinson, D. 1992. In situ hybridisation: A practical approach. IRL Press, Oxford University, UK.

Wilson, P.A. and A. Hemmati-Brivanlou. 1995. Induction of epidermis and inhibition of neural fate by Bmp-4. Nature 376: 331-333.

Wilson, P.A. and D.A. Melton. 1994. Mesodermal patterning by an inducer gradient depends on secondary cell-cell communication. Curr. Biol. 4: 676-86.

Winnier, G., M. Blessing, P.A. Labosky, and B.L.M. Hogan. 1995. Bone morphogenic protein-4 is required for mesoderm formation and patterning in the mouse. Genes \& Dev. 9: 2105-2116.

Wrana, J.L., L. Attisano, R. Wieser, F. Ventura, and J. Massagué. 1994. Mechanism of activation of the TGF- $\beta$ receptor. $\mathrm{Na}$ ture 370: 341-347.

Yamaguchi, T.P., K. Harpal, M. Henkemeyer, and J. Rossant. 1994. fgfr-1 is required for embryonic growth and mesodermal patterning during mouse gastrulation. Genes \& Dev. 8: $3032-3044$

Zhou, X., H. Sasaki, L. Lowe, B.L. Hogan, and M.R. Kuehn. 1993. Nodal is a novel TGF- $\beta$-like gene expressed in the mouse node during gastrulation. Nature 361: 543-547. 


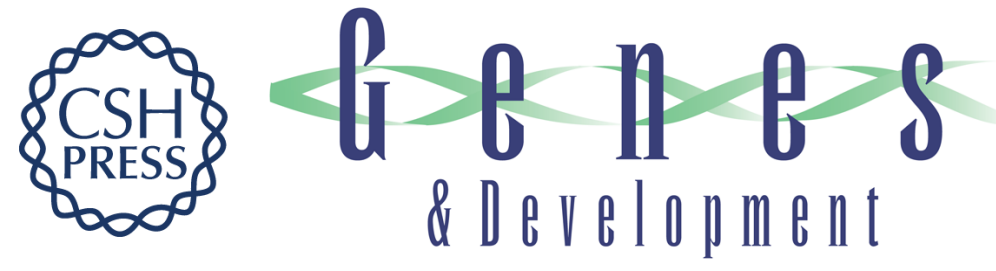

\section{A novel mesoderm inducer, Madr2, functions in the activin signal transduction pathway.}

J C Baker and R M Harland

Genes Dev. 1996, 10:

Access the most recent version at doi:10.1101/gad.10.15.1880

References This article cites 59 articles, 29 of which can be accessed free at:

http://genesdev.cshlp.org/content/10/15/1880.full.html\#ref-list-1

License

Email Alerting

Service

Receive free email alerts when new articles cite this article - sign up in the box at the top right corner of the article or click here.

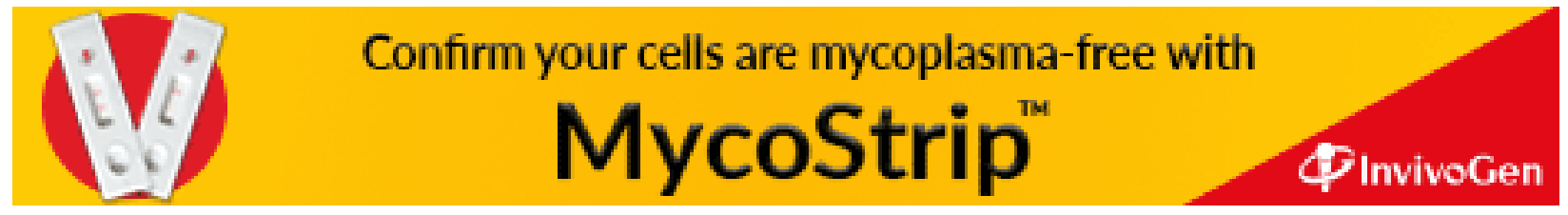

